\title{
UITDAGINGS AAN DIE LEIERSKADER VIR DIE ONTWIKKELING VAN DIE MENSEKRAGTE VAN DIE SA WEERMAG VIR DIE JAAR 2000 PLUS
}

Skout-admiraal R. Eherlein SD DEd*

\section{INLEIDING}

Die leier in die SA Weermag (SAW) verkeer werklik in 'n bevoorregte posisie. Met leiers word bedoel persone op veral die middelbestuurs- en toesighouersvlakke, hetsy offisier, adjudant-offisier of onderoffisier. Nie alleen staan hy midde-in seker die opwindendste tydperk in die geskiedenis van ons land nie, maar daarby het hy die voorreg om deel te neem aan die veranderings en uitdagings, wat gestalte sal gee aan die SAW van die jaar 2000 plus. Hy het ook die geleentheid om tot die vorming van die enkel belangrikste faktor van die SAW van daardie tyd: die mens, by te dra.

Dit is onnodig om in besonderhede die verrykende veranderings van die jaar 1990 uiteen te sit. Veranderings soos dié wat strek vanaf die Staatspresident se verklarings van 2 Februarie 1990, na onderhandelings waarop die toekoms van die Republiek berus, tot stakings, onrus en onlus wat blykbaar orals uitbreek, om van die verwikkelinge in die Midde-Ooste nie eens te praat nie! Die massamedia propageer elke dag hulle weergawes daarvan. Dit is seker voldoende om te sê dat die Sjinese vloek: "Mag u in interessante tye leef" uiters toepaslik is.

\section{VEELVOUD VAN UITDAGINGS}

In twee vorige artikels (Eberlein 1990a: 28 en Eberlein 1990b: 31) is 'n strategie vir die ontwikkeling van die mensekragte en die rol van opvoedkundige tegnologie dárvoor in die SAW uiteengesit en dit hoef nie hier herhaal te word nie. Wat egter belangrik is, is die uitdagings wat dit bied aan die leier in die SAW wat met leiding en bestuur van mensekragte gemoeid is.

Terloops, die belangrikheid van die leier en van leierskap in ' $n$ organisasie, en die bydrae daarvan tot die sukses van die organisasie het slegs ná die werk van Peters en Austin (1985:5) regmatige erkenning begin geniet. Voorheen is bestuur ("management") as die bepalende faktor in organisasiesukses beskou.

Die voortbestaan en sukses van 'n professionele SAW vereis dat die leier opgewonde moet word oor genoemde veranderings en uitdagings en sy lyf moet omgord om die uitdagings die hoof te bied. Die probleem is egter dat daar soveel veranderings en uitdagings is dat mens heeltemal verward raak, en nie weet waar om te begin nie!
In rekenaarterme ly die leier aan inligtingsoorlading en het die sentrale verwerkingseenheid en die periferale net nie die kapasiteit nie. Verwarring heers!

"Ons het twee kanse", soos dit in ligte luim gestel word. Volg óf die parodie van die goeie ou Vlootseevaartreël, wat lui:

"When in danger or in doubt,

Run in circles,

Scream and Shout!"

(Manual of Seamanship Vol II 1951:567), óf die beproefde tegnieke van die militêre waardering moet toegepas word en moet daar:

data ten opsigte van die probleem ingesamel word:

die doel bepaal word;

faktore en alternatiewe optredes geïdentifiseer word ensomeer, en 'n optimale oplossing gekies en daarmee aangegaan word.

(Reëls van Militêre Skryfwyse 1982:9-2).

Nadere ondersoek van die data relevant by die huidige situasie en by die werk van die leier is nou aan die orde van die dag.

Hierdie data kan heel sinvol in terme van die werksomgewing, die werkinhoud en die werkuitdaging bestudeer word (Whyte, 1990:4).

\section{WERKSOMGEWING}

\section{Interaksie tussen Organisasie en Omgewing}

Die term "eksterne werksomgewing" verwys na die eksterne omgewing waarbinne die werk verrig sal moet word en "interne werksomgewing" dié binne-in die organisasie ("Job context environment") soos beskryf deur Gerber et al (1987:91). Hier word nie slegs die fisiese omgewing bedoel nie, maar die breë konteks waarbinne die organisasie funksioneer.

Een van die fasette van die era van holistiese bestuur waarbinne die leier nou leef, is die klem wat op die belangrikheid van die interaksie tussen die organisasie en sy lede (in hierdie geval die SAW) en die omgewing gelê word (Whyte 1990:4).

Dit was nie altyd so nie. Daar is van die ouer lede wat bv kan onthou hoedat die SAW homself as ' $n$ entiteit beskou het, ' $n$ eiland geskei en onafhanklik van die res van die samelewing. 
Voorbeelde van hierdie optrede kon gesien word in die bestaan van geslote, selfvoorsienende militêre gemeenskappe, waar in al die lid se behoeftes voorsien is. Hy het in die militêre gebied gewerk, 'n militêre huis bewoon, inkopies by 'n militêre winkel gedoen, kerkdienste in ' $n$ militêre kerk bygewoon, sy kinders het soms selfs in die militêre gebied skoolgegaan, hy het in die militêre gemeenskap sosiaal verkeer, en is uiteindelik daar begrawe. Enige belangstelling of beweging buite die geslote militêre gemeenskap is ontmoedig, en dit was in werklikheid nie nodig nie.

Deesdae is dit anders. Lede werk saam met lede van private organisasies in geboue in die middestad. Hulle word volwaardige lede van ander gemeenskappe, besit hulle eie huise, het 'n wyer vriendekring, woon kerke in hulle nuwe woongebied by, is leiers in en neem deel aan talle aktiwiteite wat op die oog af niks met die militêr te doen het nie.

Dit is maar net ' $n$ voorbeeld van die toenemende simbiose tussen die organisasie, sy lede en die omgewing wat die organisasie, sy lede en spesifiek die leier en sy werk, raak.

Dit kom daarop neer dat geen organisasie in ' $n$ vakuum kan funksioneer nie, veral nie die SAW wat 'n "volksweermag" is nie. Die militêre leier en bestuurder moet in die toekoms bereid wees om gekonfronteer te word met radikale veranderinge, risiko's en onsekerhede wat maar verlengstukke is van die dinamika van die eksterne werksomgewing, sowel as met die onvoorspelbaarheid van menslike gedrag in en om die organisasie (Nasionale Opleidingsraad, 1990:1).

\section{FAKTORE IN DIE SUID-AFRIKAANSE OMGEWING WAT DIE WERKSOMGEWING RAAK}

\section{Bevolkingsaanwas en die Arbeidsmag}

In 'n vorige geskrif (Eberlein 1990a:29) is aangedui dat die bevolking van Suid-Afrika tussen nou en die jaar 2000 met ongeveer 12,6 miljoen mense gaan toeneem. Daarvan sal ongeveer 11,1 miljoen swart, en 1,6 miljoen uit die ander bevolkingsgroepe kom. Vir die SAW leier is sekere van die eienskappe van hierdie bevolking belangrik.

Eerstens gaan die blanke, Indiër-, en kleurling bevolking effektief "ouer" word, wat kan beteken dat die aantal jongmense uit hierdie groepe wat hulle vir die SAW en diensplig beskikbaar maak, gaan verminder.

Tweedens gaan die swart bevolking daarenteen meer jonger mense bevat, talle van wie in 'n militante milieu sonder effektiewe ouerleiding grootgeword het (Nasionale Opleidingsraad, 1990:42). Die houding teenoor die SAW van hierdie jong, potensiële lede sal dalk nie so gunstig wees as wat verlang word nie.

Derdens gaan daar ' $n$ surplus van meer as 3 miljoen akademies geskoolde matrikulante, en 'n tekort van meer as 65000 graduandi en 37000 diploma-kwalifiseerdes wees. Die SAW se behoefte lê nie soseer in akademiese as in gevegs- en tegniese vaardighede nie. Daar moet dus afgelei word dat klem in die toekoms op opvoeding en op heropvoeding sowel as op opleiding gelê sal moet word om hierdie bronne effektief te kan benut.

Vierdens is die huidige aanduidings dat $8-10$ miljoen van die totale bevolking van 44,8 miljoen, werkloos gaan wees. Werkloosheid het gepaardgaande probleme van armoede, losbandigheid en wetsongehoorsaamheid wat die aanwendingsrol van die SAW kan affekteer.

\section{Verstedeliking}

Die bevolkingsaanwas vroeër genoem, gaan tot gevolg hê dat die verstedelikingsproses wat onlangs begin versnel het, verdere stukrag gaan toon. Aanduidings is dat waar daar in 1980 slegs ongeveer 6 miljoen lede van die swart bevolking in stedelike gebiede gebly het, dié syfer tot tussen 15 en 18 miljoen binne die volgende 15 jaar sal styg (ibid:ii).

Gekoppel aan die probleme van werkloosheid en militantheid, kan daar, onder andere, hieruit afgelei word dat stedelike onrus ' $n$ werklike probleem van die volgende dekade kan word, met die gepaardgaande invloed daarvan op die funksionering van die SAW (ibid:42).

\section{Ekonomiese Realiteite en Produktiwiteit}

In die laaste jaar of wat het dit duidelik geword dat meer en meer geld aan sosiale opheffingsprogramme en minder aan verdediging bestee moet word. Die uitwerking hiervan op die SAW is reeds duidelik gesien en gevoel. Die rieme moes nouer gesny word om die begroting te laat klop. Ekonomiese realiteite dui daarop dat daar in die nabye toekoms geen verligting gaan kom nie, en dat daar eenvoudig geleer sal moet word om meer effektief met geld te werk en meer produktief te wees.

Verder kan voorspel word dat die groei van die rykdom van die swart bevolking gaan versnel. Van die redes hiervoor is die groter onderhandelingsmag van die swart arbeidsmag wat om beter diensvoorwaardes (en dus ook besoldiging) beding, en ook die groei van die informele en kleinsakesektore. Die implikasie van eersgenoemde is dat organisasies sal neig om minder van die duurder werknemers in diens te neem, en dus meer kapitaalintensief sal raak (Whyte 1990:4). In 'n mannekragintensiewe beroep soos die SAW, beteken dit egter 'n wesentlike 
intensifisering van personeelbestuur om dieselfde aantal of selfs minder mense in diens te kan hou, en verdere beklemtoning van die behoefte aan beter benutting van die mensekragbronne van die SAW. ' $n$ Belemmerende faktor is egter die bekende tekort aan bestuurslui in die land (Nasionale Opleidingsraad, 1990:68).

\section{Politieke Verandering}

Wat op die politieke front aan die gang is, is nie vir ' $n$ apolitiese organisasie soos die SAW te bespreke nie. Wat egter wel vir die leier belangrik is, is die uitwerking op Weermagmense van hierdie veranderings en die gepaardgaande onsekerheid.

Verandering bring daarmee saam onsekerheid, stres, frustrasie en weerstand. Snelle verandering vermenigvuldig hierdie simptome en affekteer die lewenskwaliteit en funksionering van die lede nadelig. As gevolg van 'n mate van onstabiliteit in beide die werksituasie en die gemeenskapslewe, moet die leier aanvaar dat lede in die korttermyn ' $n$ weerstand tot verandering sal ontwikkel, en sal hy gevolglik strategieë en tegnieke moet ontwikkel vir die vroegtydige identifisering, behandeling en bestuur van hierdie verskynsels (Albrecht, 1979:115).

\section{Nywerheidsverhoudinge}

Nywerheidskonflik sal waarskynlik op 'n hoë vlak in die jare 1990 bly (Whyte 1989:5).

Dit kan vir sommige mense ' $n$ verrassing wees, maar ten spyte van beskermende wetgewing, het die SAW reeds die arena van nywerheidsverhoudinge binnegegaan. Tentatiewe pogings vind plaas deur verteenwoordigers van vakbonde om 'n houvas te kry op veral die Algemene Assistente en daar moes reeds opgetree word.

Die term arbeidsverhoudinge (of nywerheidsverhoudinge) gaan vir die militêre persoon gepaard met die verskynsel van stakings, verplasing en uitsluiting, wat deur baie van ons burgelike kollegas ondervind word.

Die beoogde veranderings aan die Wet op Arbeidsverhoudinge wat moontlik lidmaatskap van vakbonde en personeelverenigings vir lede van die Staatsdiens kan reguleer, sal ' $n$ hele nuwe werksgebied vir die leier binnelei. Al word die SAW grotendeels uitgesluit uit hierdie beoogde veranderings, sal daar in die gees van die wetgewing opgetree moet word. Dit beteken dat die (bestuurs-) beginsels van billike arbeidspraktyk, soos griewe- en dissiplinêre prosedures toegepas sal moet word.

Hierdie beginsels is egter nie vreemd nie, maar beginsels wat reeds in die strukture, reëls en regulasies, en kodes van die SAW vervat is. Genoemde beginsels sal egter moet afgestof en aangepas word om aan die nuwe vereistes te kan voldoen.

Die treffendste eienskap van nywerheidsverhoudings in die jare tagtig was die regskleur wat aan bestuurder-/werkerverhoudings gegee is. Dit kom voor asof regsaspekte egter nou te veel aandag geniet en die einddoel van goeie verhoudings uit die oog verloor is (Whyte, 1989:6).

Die SAW sal moet poog om uit die foute en ervaringe van sy burgerlike eweknieë te leer. Daar sal moet weggebly word van die streng wetsaspekte van arbeidsverhoudinge en in plaas daarvan moet die geleentheid gebruik word om goeie verhoudinge in die werksmag uit te bou. Daar moet gestreef word om dit te bepaal en te bereik wat gemeenskaplik in die doelwitte van bestuur en van die werksmag is.

\section{Tegnologie}

Simplisties gestel, kan verwag word dat die SAW van die toekoms die vermoë sal moet hê om 'n hoë tegnologiese (moontlik konvensionele) bedreiging, met ' $n$ relatiewe klein groep uitgesoekte mense van hoë tegniese kundigheid; en 'n laer tegnologiese (waarskynlik onkonvensionele of anti-terroris-) bedreiging wat veel laer kundigheid in groter groepe mense vereis, te kan hanteer. Hierdie saak is vroeër in meer besonderhede bespreek (Eberlein: 1990b:32).

\section{FAKTORE IN DIE SA WEERMAG WAT DIE WERKSOMGEWING RAAK}

Uit die talle veranderings wat tans in die SAW plaasvind, kan twee as van wesentlike belang vir die leier, tw die veranderende organisasiestruktuur, en die kultuur, uitgesonder word.

\section{Nuwe Organisasiestruktuur}

Dit is alombekend dat die SAW deur ' $n$ rasionaliseringsfase gaan. Daar word indringend gekyk na die huidige organisasiestruktuur met die oog op groter bestuurselfstandigheid van die elemente van die organisasie; ná die uitskakeling van duplikasie en burokrasie en ná die vermindering van die veelvoud van organisatoriese vlakke in die hiërargie.

Die eerste resultate hiervan is reeds te bespeur in bv die kleiner SA Vloot, die rasionalisering van vliegopleiding in die SA Lugmag, en die desentralisering van talle funksies na Weermagsdele vanaf Afdeling Personeel.

Daar is talle ander voorbeelde hiervan, wat almal op 'n dringende behoefte aan beter werwing, keuring, benutting en bestuur van beskikbare mensekragte dui. 


\section{Nuwe Militêre Kultuur}

Dit is voor die hand liggend dat al die veranderings wat aan die gang is die wese van die SAW gaan raak: die samestelling van die SAW se arbeidsmag, die wyse waarop dinge gedoen word en die verandering in struktuur. ' $n$ Nuwe kultuur sal ontwikkel moet word, 'n kultuur wat aan die vereistes van die toekoms kan voldoen. Kultuurverandering neem lank (Eberlein, 1990:33). Baie van die huidige lede sal lank reeds in die aftree-oorde sit voordat die veranderings werklik sigbaar word. Dienende leiers het egter elkeen ' $n$ bydrae te maak tot daardie nuwe militêre kultuur solank hulle nog dien.

\section{Werkinhoud}

Watter uitwerking kan hierdie faktore in die eksterne omgewing op die werk en werkinhoud van die leier per se in die SAW hê? ' $n$ Redelike groot uitwerking, want soos vroeër aangedui, kan dit wat "daarbuite" en "hierbinne" aangaan, weens die interaksie tussen die SAW en die omgewing, in die toekoms inbreuk maak op die leier en hom dus dwing om meer aandag te skenk aan sekere aspekte van sy werk as aan ander. Dit wil voorkom asof daar veral aan drie aspekte spesifieke aandag gegee sal moet word:

\section{a. Dienslewering en verantwoording \\ b. Bemanning en indienshouding \\ C. Opleiding en ontwikkeling}

\section{DIENSLEWERING EN VERANTWOORDING}

\section{Die Konsep van Dienslewering en die Pro- fessionele Organisasie.}

Daar kan ten minste twee betekenisse geheg word aan die konsep van dienslewering. Die een gaan oor lewering van gehaltediens aan 'n kliënt (Eng: Service), en die tweede oor lewering van resultate, "die doen van dinge".

Gekombineerd kan hulle as die kenmerk van 'n professionele organisasie (Ball en Ashbury, 1990:154), dienslewering en gehalte gesien word.

Vir 'n krygspraktisyn val die konsep van dienslewering dalk vreemd op die tong, aangesien dit normaalweg met kommersiële organisasies geassosieer word. Dit is dalk goed-en-wel vir Pick-'n-Pay, maar vir die SAW? Nooit!

Die toepassing van die konsep kan dalk die beste deur die volgende voorbeeld geillustreer word.

Miskien is aanhaling wat in die geskiedenis van leierskap en bestuur die meeste misbruik word, die volgende:
"Die mens is die belangrikste enkele faktor'".

Indien die aanhaling wel waar is, is dit ook waar dat meer lippehulde aan hierdie konsep gebring word as wat werklik in die praktyk toegepas word.

Die konsep van dienslewering is nie vreemd nie. Dit wil egter voorkom asof dit, bv in die personeelwêreld verswelg word deur verskonings vir die nielewering daarvan. Hierdie verskonings wissel vanaf reëls en regulasies wat dienslewering verbied tot die soeke na redes om te verhoed dat die lid die diens kry wat hy heel duidelik na smag en waarvoor die personeelspesialis betaal word.

Die toenemende beklemtoning van verantwoording, kostes en meetbare resultate, saam met ' $n$ besef van die ekonomiese mag van die groot publiek, stafverenigings en vakbondbewegings sal toenemende druk vir dienslewering op die personeelspesialis plaas. Dalk eers dan sal hy besef dat diens aan die belangrikste faktor, die mens, gelewer moet word. So nie, sal hy sy eie bestaansreg moet regverdig.

\section{Voorsiening van Meetbare Resultate en Ver- rekening van Onkostes}

Op dieselfde wyse kan gepraat word van "die doen van dinge" en die lewering van meetbare resultate.

Dit het amper tradisie geword dat die leier, wanneer daar gevra word oor die meting van sý werksresultate, dit weglag met: "maar jy weet mos, bestuur kan nie gemeet word nie!"

Bevelvoerders op alle vlakke kan en sal daarop aandring dat die bydrae van die leier tot die sg "bottom-line" - die doelwitte van die SAW - in terme van resultate en kostes sigbaar gemaak word.

In die proses van verrekening van kostes en die voorsiening van meetbare resultate kan die tegnologie, en veral die rekenaar, 'n onmisbare bondgenoot wees.

Dit sal aan die leier wat oor die nodige kundigheid beskik, die gereedskap voorsien wat nodig is om die onvermydelike vrae wat sal opduik te kan beantwoord.

\section{Verantwoordelikheid vir Optredes}

Terwyl die konsep van verantwoording ("accountability") en aanvaarding van verantwoordelikheid ("responsibility") vir menslike aksies of optredes nie in die SAW vreemd is nie, gaan die konsep heel waarskynlik in die nabye toekoms nuwe betekenis en vorme aanneem.

Gesien uit die standpunt van devolusie van mag en die delegasie van gesag, kan leiers in 
die toekoms hulself in die beskuldigdebank vind wanneer hulle persoonlik voor die Gekose Komitee vir Openbare Rekeninge verskyn, in plaas daarvan dat die Hoof van die SAW namens hulle onder skoot kom.

Gesien uit die standpunt van 'n SAW met ' $n$ kleiner begroting, minder mense en minder toerusting, beteken dit beter benutting deur die SAW van mense en toerusting. Die dae van oorvloed (was daar ooit so iets?) is verby. Mense en hul toerusting sal beter moet presteer en langer hou. Die mens en die toerusting met gebreke kan nie net weggesmyt word nie, want plaasvervangers sal daar nie wees nie. Albei sal beter opgepas en hul gebreke herstel moet word om hulle in staat te stel om vir langer tydperke die doelwitte van die SAW te kan bereik.

\section{BEMANNING VAN DIE ORGANISASIE}

Dit is alombekend dat daar ' $\mathrm{n}$ nypende tekort aan vaardighede in die tegniese, professionele en bestuursrigtings is. Die tekort is sodanig dat baie burgerlike organisasies in die verlede hulle tekorte aangevul het deur van die SAW te "leen" of uit die immigrasiestroom aan te vul. Aan die ander kant is en sal die SAW heelwaarskynlik in die toekoms ook ' $n$ hoofvoorsiener van geskoolde mannekrag aan die land bly. Hierdie situasie sal waarskynlik onveranderd bly tensy die SAW se vermoë om die organisasie te beman en om vir sy mense te sorg ten volle ontwikkel word.

Die vermoë om in die arbeidsmark effektief mee te ding en om die organisasie te beman sal 'n hoofkenmerk word van organisasiedoeltreffendheid (Whyte 1989:5). Dit vereis ' $n$ wesentlike verbetering in mannekragbeplanning, beplanningsvermoë en keuringstegnologie sowel as gedurige aanpassing van vergoedingspakkette en diensstelsels.

Die leiers op elke vlak in die SAW sal verantwoordelikheid moet aanvaar vir die effektiewe bemanning van hul eie organisasies.

Met die veranderende samestelling van die SAW, die verandering in behoeftes van die mense in die SAW en die veranderende organisasiestruktuur en -kultuur beteken dit ' $n$ beklemtoning van en 'n groter behoefte aan professionele personeelbestuur (Eberlein, 1990b:34).

\section{Opvoeding en Opleiding}

Vir 'n organisasie met 'n sterk basis vir opleiding, is die beklemtoning daarvan in die SAW niks nuuts nie. Die verskil wat in die toekoms egter na vore gaan kom, is dat die ekonomiese situasie en die aandrang op produktiwiteit die SAW gaan dwing om metodes te vind, om die onkostes verbonde aan opleiding ter bereiking van die SAW se doelwitte te meet.

Gevolglik sal dit toenemend meer kundigheid van die leier vereis om die geld en poging wat in opleiding ingeploeg word, te regverdig.

Uit ' $n$ opvoedingsoogpunt gesien, is sake effens meer kompleks. Die SAW en ander staatsdepartemente word tereg aangemoedig om op hul hooftaak te konsentreer, en om nie die aktiwiteite van ander departemente oor te neem nie. Opvoeding is een van die aktiwiteite wat eintlik by ' $n$ ander departement tuishoort.

Die probleem is egter dat die SAW vir die voorsienbare toekoms sal aanhou om mense te lok wat, alhoewel hulle op die oog af akademies gekwalifiseerd is ('n surplus van matrikulante word voorspel) nie noodwendig opvoedkundig voorbereid is vir diens in die SAW nie. Verder kan dit voorkom dat groot getalle dienende lede, soos lede van die Hulpdiens, ook nie oor die nodige opvoedkundige kwalifikasies beskik om optimaal doeltreffend te funksioneer in die meer professionele SAW van die toekoms nie.

Dit alles dui daarop dat die SAW, as werkgewerorganisasie, opvoeding, veral geletterheidsopvoeding en werkverwante opleiding aan relatiewe groot getalle mense via die leier, sal moet voorsien.

\section{DIE WERKSUITDAGINGS}

Die hantering van die veranderings in die werksomgewing en die uitvoering van die hooftake wat die werksinhoud bied, gaan sekere uitdagings aan die leier in die SAW stel, die belangrikste waarvan hierna bespreek word.

\section{Professionele Deskundigheid}

Hier word doelbewus nie van "professionele kundigheid" ("professional knowledge or expertise") gepraat nie maar van "professionele deskundigheid" ("expert knowledge"), want die leier in die SAW van die toekoms sal 'n deskundige op sy eie professionele gebied moet wees. Die rede? Soos dit in die "Fortune" tydskrif beskryf word:

"The troops will follow a lot more willingly if they are confident that the man or woman in front knows at least as much as they do". (In Ball en Asbury, 1989:203 gekwoteer.)

Die aankondiging in 1990 van die nuwe bedeling vir die SAW (algemeen bekend as Projek DYSAN) het gepaard gegaan met die beklemtoning van die professionele aard van die werk van die militaris. Die term "krygspraktisyn" ("Military Practitioner") is vir die eerste maal gebruik om die professionele aard van die 
militêre beroep te beklemtoon (Projek DYSAN, 1989:VI1). Van die krygspraktisyn word verwag dat hy eerstens ' $n$ professionele militêr, moet wees en tweedens, dat hy ' $n$ deskundige in die toepassing van sy spesialis = (of funksionele) kennis in die militêre milieu sal wees (ibid:V-22).

Hierdie dubbele vereiste plaas 'n baie swaar selfontwikkelingslas en -uitdaging op die leier. Nie alleen moet hy sorg dat hy op hoogte bly van die snelle veranderings en ontwikkelings in die wetenskaplike veld van die militêre professie nie, maar hy moet ook op tred hou met die toenemende vereistes van die funksionele sy van sy professie. In die geval van bv 'n krygspraktisyn wat ook 'n personeelspesialis is, word daar van hom verwag dat hy hom akademies en prakties in twee erkende "professies" moet bekwaam.

\section{Geïnspireerde leierskap}

In die militêr word daar soms beswaar gemaak teen die gebruik van die term "bestuur" omdat dit as ' $n$ "burgerlike" term beskou word. Onder hierdie groep word daar eerder van "leierskap" gepraat. Elke konsep het egter sy plek.

\section{Soos Cronje et al dit stel:}

"Leierskap is die vermoë om andere te beïnvloed om gewillig saam te werk. Bestuur behels onder andere leierskap, maar sluit die ander elemente van bestuur, soos beplanning, organisering en beheer in" (1987:115).

Bennis en Nanus stel dit anders:

"The problem with many organisations, and especially the ones that are failing, is that they tend to be overmanaged and underled. There is a profound difference between management and leadership, and both are important. Managers are people who do things right and leaders are people who do the right things". (in Ball en Asbury, 1990:184).

Die uitdaging aan die militêre leier van die toekoms is om geïnspireerde leierskap aan die dag te lê. Hiermee word bedoel dat hy daardie dinge moet doen wat in Suid-Afrika, en veral in die SAW, sukses meebring. Volgens Ball en Asbury (1990:186 et seq) moet dié leier:

a. 'n Visie hê. ' $n$ Visie is 'n ideaal waarna gestreef word, wat inspirasie vir die lede van die organisasie kan word.

b. Opgewondendheid skep. ' $n$ Leier kan nie van sy mense verwag dat hulle meer opgewonde oor sy visie en die SAW moet wees, of meer betrokke moet wees as wat hy self is nie. In die militêr moet hy die visie, die dinge van die SAW en die krygspraktisyn eet, leef en slaap. Soos in die dae van weleer is sy prioriteite éérs die Weermag, dán sy vrou en kinders, en eers daarna sy perd of motor!

c. Die organisasie dryf. In die SAW moet die leier heel duidelik in beheer wees, die pas aangee ('n stywe pas) en sy mense saam met hom vorentoe trek. ' $n$ Woord van waarskuwing is egter hier nodig. 'n Leier gee die pas aan, stel die voorbeeld, tree as rolmodel op. Dit is almal positiewe beskrywings van ' $n$ benadering tot leierskap. In sommige kringe in die SAW (veral op die junior vlak) het daar 'n negatiewe benadering tot leierskap ingetree. Ter illustrasie: die sg "leier" op die 2,4 km fiksheidstoets wat die toets in sweetpak en hardloopskoene aflê, terwyl sy troepe in nutria en stewels geklee is en 'n geweer dra. Verder: die benadering wat vereis dat die troep fisies uitgeput moet word ("gelooi word") om sy motivering op die proef te stel. Dit is twyfelagtig of dit ware leierskap is en of dit in hierdie tyd nog van toepassing is.

d. Inspekteer. Hierdeur bewys die leier dat hy in beheer is; dat hy aktueel in voeling bly; dat hy weet hoe dinge gedoen moet word, en laastens dat mense van hom terugvoer oor prestasie en probleme kan verwag. Peters en Austin noem dit "MBWA" ("Management by walking around") (1985:8).

e. By die aktualiteite uitkom. Leierskap word nie van agter 'n lessenaar uitgeoefen nie. Of die leier in die gevegslyn staan of in ondersteuning, bly sy primêre taak veral om op hoogte van aktualiteite te bly wat (Eng: Coalface) van toepassing op sy spesifieke funksie is. Dit beteken dat hy eerstehands moet uitvind waar die probleme lê en wat die probleme in die hoofkwartier, kommandement of eenheid werklik is.

f. Die weg baan. Die leier moet geleenthede identifiseer en gebruik om die doelwitte van die SAW te bereik en om die visie daarvan te verwesenlik. Die konsep van "opportunistiese pragmatisme", soos later beskryf, is hier van toepassing.

g. Spesifieke en hoë eise stel. Die leier moet spesifiek weet wat hy wil hê of wil bereik. Hy moet van mense verwag dat hulle tot die uiterste perke van hul vermoëns moet strewe om die eise te bevredig (Coutts-Trotter in Ball en Asbury, 
1989:194). Mense kan veel meer vermag as wat hulle sou dink. Anders gestel:

"Mense is wat van hulle verwag word om te wees".

h. Kultuur kan skep. Die leier moet die gewensde kultuur van die SAW kan definieer en dit dan uitdra en uitleef.

i. Kommunikeer. In 'n organisasie so groot soos die SAW is doeltreffende kommunikasie 'n wesentlike probleem. Die suksesvolle leier skep geleenthede en meganismes vir kommunikasie. Hy maak gebruik van ordergroepe, informele gesprekforums, videoprogramme, tydskrifte, omsendbriewe, daaglikse orders, sosiale geleenthede en sportbyeenkomste om sy boodskappe, behoeftes en betrokkenheid oor te dra.

j. Vir sy mense sorg. Met enkele uitsonderings, beskik die beste organisasies nie alleen oor uitstekende leiers nie, maar ook oor uitstekende bestuurspanne. Die leier in die SAW moet in staat wees om die beste mense in diens te behou. Dit doen hy deur mense na hom te trek, en vir hulle te sorg voordat hy aan sy eie behoeftes aandag gee. Die wa kan nie deur die leier alleen deur die drif gesleep word nie.

Indien dit alles te idealisties klink, kan daar net terug gedink word aan die basiese vereistes wat aan die militêre leier gestel word. Tussen daardie en hierdie vereistes is daar min verskil; dalk is die terminologie net anders.

\section{Kreatiewe Leierskap}

Die konsep van leierskap teenoor dié van bestuur is vroeër bespreek. Die uitdaging is egter om kreatiwiteit in leierskapsoptrede in te voer, om nuwe, dalk voorheen ondenkbare oplossings en visies vir sowel die ou as die nuwe probleme en uitdagings aan te bied en te kultiveer.

Die veranderings wat plaasvind gaan ook vereis dat 'n nuwe leierskapstyl ontwikkel en gevolg moet word. Die ou geykte militêre styl van outokratiese leierskap sal aangevul moet word met nuwe, buigbare situasie-gebonde leierskapstyle wat aan die nuwe vereistes van kreatiewe, onderhandelde oplossings vir die toekoms sal kan voldoen (Schilbach, 1983:183).

Daarby sal die kreatiewe leier:

a. kreatiwiteit in ander moet ontwikkel en lei;

b. buigsaamheid in denke moet aanmoedig; c. mensewaardes wat onderliggend is aan uitnemendheid in die SAW moet identifiseer en vestig. (Greene 1987:91).

\section{PROFESSIONELE BESTUUR}

Die volgende dekade gaan 'n groot premie op bestuursvermoëns plaas in die sin dat bestuur in die toekoms in ' $n$ groter mate aan die vereistes van professionele bestuur sal moet voldoen (Nasionale Opleidingsraad, 1990:59).

Nie alleen beteken dit dat bestuur oor die fundamentele vaardighede en take van bestuur moet beskik nie, maar beteken dit ook dat intellek ' $n$ groter rol as voorheen gaan speel (ibid:60).

Met die fundamentele vaardighede en take van bestuur word bedoel:

a. Beplanning: Bestuur besluit oor wat gedoen moet word. (Dit sluit in bepaling van rigting, doelwitte, hulpbronne en wyse om planne te verwesenlik.)

b. Organisering: Bestuur se besluit oor hoe dit gedoen moet word. (Dit behels die daarstelling van struktuur en voorsiening van mensekragte.)

c. Leiding: Bestuur se bepaling van hoe en wanneer dit gedoen moet word. (Dit verwys veral na die opdragte aan en die motivering van die mense om uitvoering aan die planne en doelwitte te gee.)

d. Beheer: Bestuur se vasstelling of die opdragte uitgevoer en doelwitte bereik is of nie (Cronje et al:72).

Wat die rol van intellek betref, begin dit duidelik word dat intellek ' $n$ groter gewig as parate kennis sal dra, aangesien laasgenoemde so vinnig verouder, terwyl 'n aanpassingsbenadering bestuur van die plooibaarheid voorsien om omgewingsveranderinge met sukses te hanteer (Nasionale Opleidingsraad 1990:60).

Wat die rol van die leier betref, behoort dit duidelik te wees dat sy funksie ingeweef is in al die fundamentele vaardighede en take van bestuur en die deurslaggewende faktor in die suksesvolle afhandeling daarvan is.

Die SAW maak voorsiening vir die professionele ontwikkeling van die leier (en die bestuurder), en die uitdaging aan lede is dus om gebruik te maak van geleenthede wat aangebied word.

Die leier sal moet sorg dat sy ontwikkeling voorsiening maak vir al die nuwe vaardighede wat vereis word deur veranderings in leierskaps- en bestuurstyle, arbeidsverhoudings, opvoeding en opleiding, en in die kultuur van die SAW van die toekoms. 


\section{STRATEGIESE BESTUUR}

Indien die leier op alle vlakke te doen gaan hê met aspeḱte van die oorlewing en groei van die SAW, sal hy moet leer om 'n strategiese bestuursbenadering te volg.

Dit beteken nie dat dit nie in die verlede gedoen is nie, maar dat daar die neiging is om "gekompartimentaliseerd" op te tree, om die verskillende funksies as onafhanklike funksies te beskou en om "ons eie ding te doen" sonder om werklik ander en veral die lynfunksie, se behoeftes in ag te neem.

Dit was miskien deels te wyte aan die feit dat die belangrikheid en professionele aard van ondersteuningsfunksies nie werklik deur die lynfunksie erken is nie. Dit kan miskien nog so wees, maar dit moet nie in die toekoms geduld word nie.

'n Strategiese bestuursbenadering vereis dat leiers oor die vermoë moet beskik om holisties te dink en te redeneer. Hulle moet kort-, medium- en langtermynbeplanning kan visualiseer en hulle deel van die SAW se posisie relatief tot die res van die SAW, die SAW familie en plaaslike, nasionale en, indien van toepassing. internasionale gemeenskappe kan posisioneer (Nasionale Opleidingsraad, 1990:52).

\section{DIE BESTUUR VAN VERANDERING}

Uit die voorafgaande moet dit vir die leier duidelik wees dat een van sy belangrikste take in die toekoms juis die bestuur van verandering sal wees.

Bestuur van verandering vereis dat leierskapsen bestuursvaardighede gebruik word om verandering te rig en om die duister en bedreigings van die toekoms te omskep in ' $n$ helder visie en uitdagings. Met behulp van 'n visie, ' $n$ ideaal waarna gestrewe word, kan die leier soos ' $n$ ryloper optree en geleenthede kaap om hom by sy doel uit te bring. Soos ' $n$ ryloper ' $n$ doelwit het, het die leier met ' $n$ visie ook 'n doelwit, alhoewel dit nie so klinklaar en helder mag wees nie. Die ryloper wat die pad na sy bestemming ken, kan enige geleentheid gebruik wat naastenby in daardie rigting vervoer verskaf, al beteken dit dalk ' $n$ effense afwyking van die direkte roete. As hy die geleentheid reg gebruik, eindig hy nader aan sy bestemming.

So ook kan die leier geleenthede gebruik om uiteindelik by sy bestemming uit te kom. Hierdie proses kan as "opportunistiese pragmatisme" beskou word.

Met hierdie benadering moet die leier ' $n$ visie skep waarvolgens hy vorentoe kan beweeg.
Hierdie visie behoort elemente van die gemeenskaplikheid van die doelwitte van die mens en die organisasie te vervat; die hantering van die mens as die belangrikste element in die organisasie; besluitneming gebaseer op gesonde oordeel en beginsels en nie suiwer op ou geykte prosedures nie; deelnemende bestuur in plaas van net outokratiese optrede; die belangrikheid van waardestelsels, esprit de corps en van mites en helde. Hieruit kan 'n toekoms vir almal geskep word. Hieruit kan die toekoms gebou word.

\section{SLOT}

Hierdie artikel volg op artikels oor 'n strategie vir die ontwikkeling van die mensekragte van die SAW vir die jaar 2000, en oor die rol van opvoedkundige tegnologie in daardie strategie. In hierdie artikel is gepoog om van die uitdagings te identifiseer wat daardie strategie bied aan veral die middelvlak-leier-, bestuurskader en die toesighouers van die SAW.

Bespreking is gevoer oor faktore in die eksterne en interne werksomgewing, wat 'n uitwerking het op die leierskader, en daar is gekonsentreer op

a. interaksie tussen die omgewing en die SAW;

b. die bevolkingsaanwas;

C. verstedeliking;

d. ekonomiese realiteite en produktiwiteit;

e. politieke veranderings soos dit die mens raak;

f. nywerheidsverhoudings; en

g. die tegnologie.

In die interne omgewing is melding gemaak van die veranderende organisasiestruktuur en die gepaardgaande veranderende kultuur.

Daar is afgelei dat in die werksinhoud van die leier daar veral gekonsentreer behoort te word op

a. dienslewering en verantwoording;

b. bemanning van die SAW; en

C. opleiding en opvoeding van die beskikbare mensekragte, met die gepaardgaande behoefte aan meer professionele personeelbestuur.

Hieruit word daar afgelei dat die leier in die SAW voor 'n reeks uitdagings staan, waarvan die suksesvolle hantering sy toekoms in die professionele SAW van die toekoms sal bepaal. Daar word van hom verwag om: 
a. 'n Professionele deskundige te wees. In beide fasette van sy gekose leefwyse, dws as krygspraktisyn en as funksionele spesialis, moet die leier as deskundige (nie net as kundige nie) optree.

b. 'n Geïnspireerde leier te wees. 'n Geinspireerde leier met 'n visie en dryfkrag, maar met sy voete vas op die grond. 'n Leier wat sy leierskap uitleef onder sy mense, wat 'n voorbeeld stel, vir sy mense sorg en nie die huidige patroon volg van "maak soos ek sê en nie soos ek maak nie". Een wat op "sy voete kan dink" en kreatiewe oplossings vir nuwe probleme kan genereer.

c. 'n Professionele bestuurder te wees. 'n Bestuurder wat nie alleen oor die kennis van die bestuurswese beskik nie, maar wat ook in staat is om die plooibaarheid te voorsien om omgewingsveranderinge met sukses te hanteer. Een wat holisties kan dink en redeneer, en wat kort- en langtermynbeplanning kan visualiseer. Een wat daarby in staat is om leiding te neem en sy visie van die toekoms te kan gebruik om die toekoms te rig en te bestuur.

\section{'n Laaste Gedagte}

In hierdie komplekse, snelveranderende wêreld help dit soms om op 'n enkele konsep te konsentreer. So 'n konsep is:

"Die krygspraktisyn moet weet wat die regte dinge is om te doen, en hulle reg doen!"

* Skout-admiraal (dr) R. Eberlein S.D. is Hoofdirek-
teur Mannekragontwikkeling SAW.

\section{Bibliografie}

1. Albrecht, K. 1979. Stress and the manager. Prentice-Hall Inc. Englewood Cliffs, New Jersey.

2. Ball, A. and Asbury, S. 1989. The winning way. Jonathon Ball Publishers, Johannesburg.

3. Cronje, G de J., Neuland, E.W. en van Reenen, M.J. 1987. Inleiding tot die bestuurswese. Southern Boekuitgewers, Johannesburg.

4. Eberlein, R. 1990a. A strategy for the development of the human resources of the SA Defence Force for the year 2000. In MILITARIA Vol 20 No 2, 1990 Pretoria.

5. Eberlein, R. 1990b. The role of educational technology in the development of the human resources of the SA Defence Force for the year 2000. In MILITARIA Vol 20 No 3, 1990 Pretoria.

6. Gerber, P.D., Nel, P.S. and van Dyk, P.S. 1987. Human Resources Management, Southern Book Publishers, Johannesburg.

7. Greene, G.P. 1987. Future executive and management training needs in Canada - a national survey. Business Quarterly, Vol. 51, March.

8. Manual of Seamanship Vol II, 1951. Her Majesty's Stationery Office, London.

9. Nasionale Opleidingsraad, 1990. Die veranderende rol van bestuur oor die volgende dekade - 'n kritiese beskouing. Pretoria.

10. Peters, T. and Austin, N. 1985. A Passion for Excellence. Collins, London.

11. Projek DYSAN, 1989. Hoof van Staf Personeel van die SA Weermag. Pretoria.

12. Reëls van Militêre Skryfwyse, 1982 (soos gewysig). Hoof van Staf Personeel van die SA Weermag, Pretoria.

13. Schilbach, C. Die ontwikkeling van leierskapsvaardighede by middelvlakbestuurders. Ongepubliseerde DCom-verhandeling, Universiteit van Pretoria.

14. Whyte, G. 1990. Annual Report of the SA Board for Personnel Practice, Johannesburg. 